\title{
Actividad de la Facultad de Odontología de la UNNE con Pueblos Originarios
}

\section{La Facultad de Odontología de la UNNE} desde el año 2007 desarrolla actividades en forma continua, de promoción, educación, prevención y recuperación de la salud, en el marco de proyectos de la Universidad en el Medio y del Programa UNNE Salud, bajo la Dirección de la Dra Maria Cristina Gómez y articulando acciones conjuntas con la carrera de Bioquímica, de la Facultad de Ciencias Exactas.
Estas actividades se desarrollan en la provincia del Chaco, en comunidades aborígenes QUOM, MÓCOI Y WICHI. Están destinadas a todos los grupos etáreos, adaptando las estrategias según los destinatarios. Los datos registrados, se utilizan como fuentes primarias epidemiológicas para encarar proyectos de investigación y extensión que permitan mejorar el estado de salud de estas poblaciones.

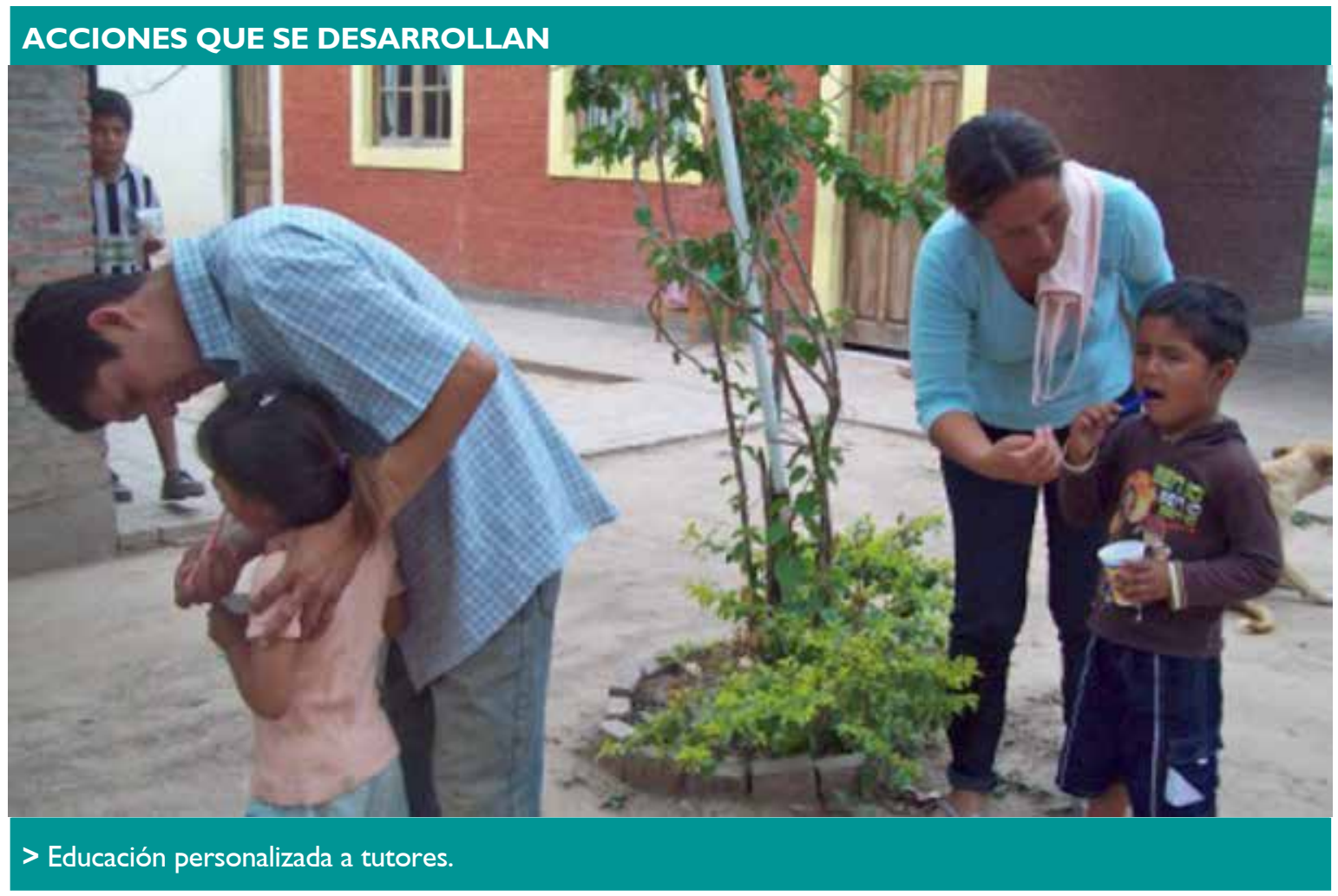


REVISTA FACULTAD DE ODONTOLOGÍA

ISSN No 1668-7280 - Vol. VII No 1 - 2014
EXTENSIÓN

55
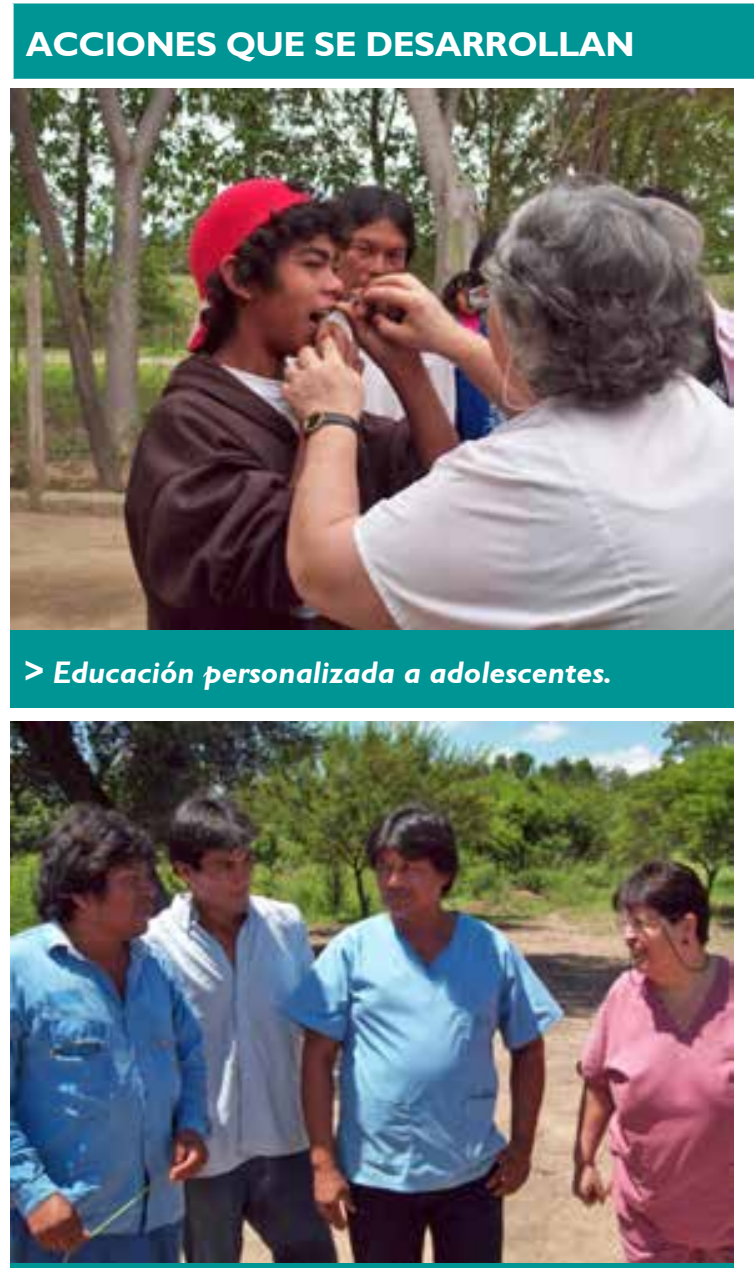

$>$ Entrevistas a líderes comunitarios.

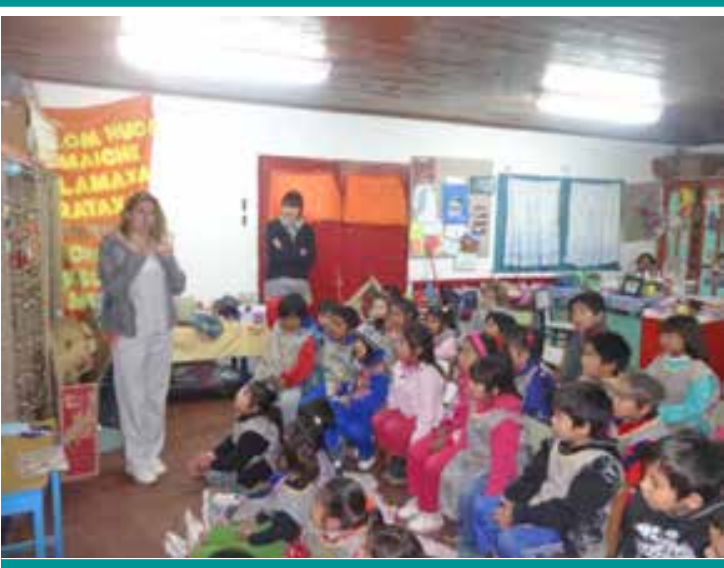

$>$ Charlas a niños de jardines maternales.

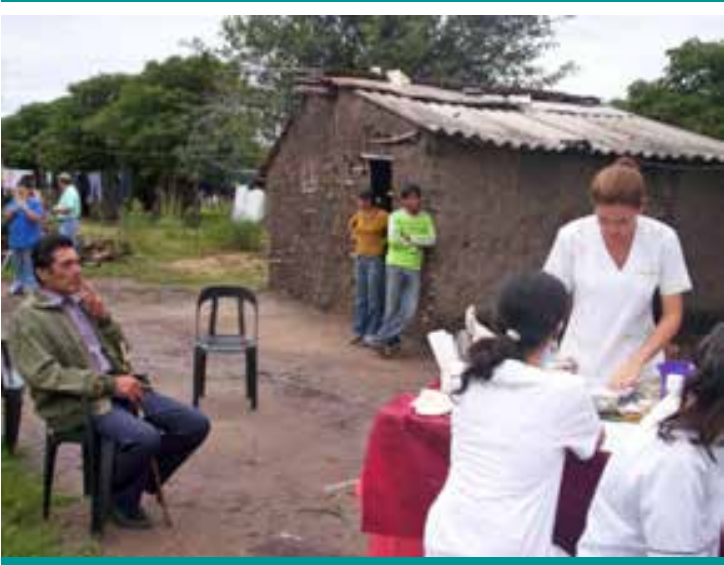

$>$ Tratamientos clínicos de recuperación de la salud bucal.

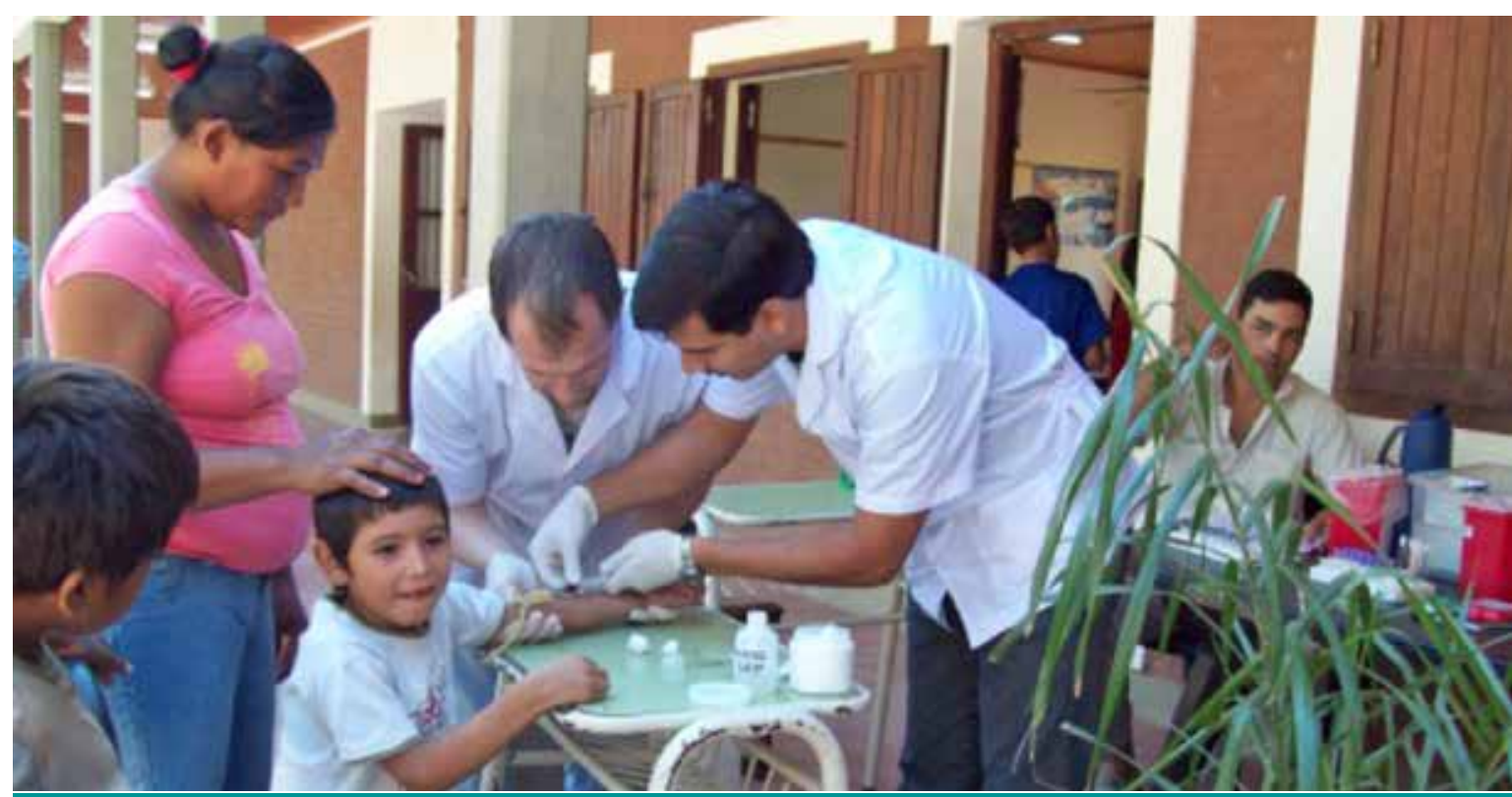

$>$ Acciones con bioquímica, con colaboración de no docentes. 